\title{
Analisis Clustering K-Means Pada Data Informasi Kemiskinan Di Jawa Barat Tahun 2018
}

\author{
Nugroho Irawan Febianto ${ }^{[1]}$, Nico Dias Palasara ${ }^{[2]}$ \\ Ilmu Komputer ${ }^{[1]}$, Sistem Informasi ${ }^{[2]}$ \\ STMIK Nusa Mandiri ${ }^{[1], \text { [2] }}$ \\ Indonesia \\ 14002181@nusamandiri.ac.id ${ }^{[1]}$,nico.ncp@nusamandiri.ac.id ${ }^{[2]}$
}

\begin{abstract}
Poverty is a condition of life that is understaffed by a person or household so that it is unable to meet the minimum or proper needs for his or her life. The poverty Data in each region will differ. It is influenced by many of its supporting indicators. By determining and measuring the indicators of poverty, it will facilitate and recognize the poverty level of the region. Grouping characteristics of a region based on poverty indicators, so that the government can precisely and quickly take policies to mitigate poverty in a region. The method used in this study uses the K-Means Clustering method. The Clustering method is selected because this method has the ability to classify large amounts of data with faster process times efficiently. The object in this study used data published by the BPS (Badan Pusat Statistik) on poverty Data and information in the Regency/city in 2018. Based on the results of this study, the results of the characteristic mapping of each group formed based on the highest and lowest value of poverty indicator of West Java province year 2018. With the characteristics found in each region, it will certainly be a solid foundation for government organizers to provide the right and quick policy/approach to overcome the poverty that is found in the region.
\end{abstract}

Keywords - Poverty, BPS, Characteristics, Data mining, Clustering, K-Means

\section{PENDAHULUAN}

Kemiskinan merupakan masalah yang cukup serius, terutama untuk di negera berkembang seperti Indonesia. Kemiskinan sebuah wilayah dalam jangka panjang akan berdampak pada terhambatnya pembangunan nasional. Kemiskinan adalah kondisi kehidupan yang serba kekurangan yang dialami seorang atau rumah tangga sehingga tidak mampu memenuhi kebutuhan minimal atau yang layak bagi kehidupannya. Kebutuhan dasar minimal yang dimaksud adalah yang berkaitan dengan kebutuhan pangan, sandang, perumahan dan kebutuhan sosial yang diperlukan oleh penduduk atau rumah tangga untuk memenuhi kebutuhan hidupnya secara layak[1].

Adapun dimensi kemiskinan menyangkut beberapa aspekaspek sebagai berikut: Aspek ekonomi, secara ekonomi, kemiskinan dapat di definisikan sebagai kekurangan sumber daya yang dapat di gunakan untuk memenuhi kebutuhan hidup dan meningkatkan kesejahteraan sekelompok orang dan Aspek Politik, kemiskinan dapat dilihat dari tingkat akses terhadap kekuasaan. Kekuasaan dalam pengertian ini mencakup tatanan sistem politik yang dapat menentukan kemampuan sekelompok orang dalam menjangkau dan menggunakan sumberdaya. Serta, Aspek sosial-psikologi, kemiskinan secara sosial-psikologis menunjukkan pada kekurangan jaringan dan struktur sosial yang mendukung dalam mendapatkan kesempatan peningkatan produktivitas[1].

Tentu saja data kemiskinan pada setiap wilayah akan berbeda. Hal ini dipengaruhi oleh banyak indikator pendukungnya. Dengan menentukan dan mengukur indikatorindikator kemiskinan, maka akan mempermudah mengenal tingkat kemiskinan suatu wilayah. Misalnya saja dapat dilihat dari seberapa banyak penduduknya yang menerima beras miskin (raskin), pendapatan ekonominya yang masih rendah, dan lain sebagainya. Oleh karena itu, dalam penanganannya pun tentu akan sangat berbeda karena harus disesuaikan dengan kenyataan yang ada di masing-masing wilayah tersebut. Dengan dikelompokannya karakteristik suatu wilayah berdasarkan indikator kemiskinan, maka pemerintah dapat tepat dan cepat dalam mengambil kebijakan untuk menanggulangi kemiskinan di suatu wilayah. Dalam hal ini, indikator kemiskinan yang digunakan telah ditentukan berdasarkan publikasi data kemiskinan Kota/Kabupaten tahun 2018 yang dirilis oleh BPS (Badan Pusat Statistik). Metode dalam pengelompokan data ini dengan menggunakan data mining.

Data mining memiliki beberapa pandangan, seperti knwoledge discover ataupun pattern recog-nition. Kedua istilah tersebut sebenarnya memiliki ketepatan masing-masing, istilah knwoledge discovery atau penemuan pengetahuan tepat karna digunakan karena tujuan utama dari data mining memang untuk mendapat pengetahuan yang masih tersembunyi di dalam bongkahan data[2]. Pandangan yang lain, Data mining adalah aktivitas yang menggambarkan sebuah proses analisis yang terjadi secara iteratif pada database yang besar, dengan tujuan mengekstrak informasi dan knwoledge yang akurat dan berpotensial berguna untuk knwoledge workers yang berhubungan dengan pengambilan keputusan dan pemecahan masalah[3]. Data mining juga

ISSN : 2301-7988

E-ISSN : 2581-0588

DOI : $10.32736 /$ sisfokom.v8i2.653 
merupakan metode yang digunakan dalam pengolahan data berskala besar oleh karena itu data mining memiliki peranan yang sangat penting dalam beberapa bidang kehidupan diantaranya yaitu bidang industri, bidang keuangan, cuaca, ilmu dan teknologi. Dalam data mining juga terdapat metodemetode yang dapat digunakan seperti klasifikasi, clustering, regresi, seleksi variabel, dan market basket analisis [4].

Analisis cluster adalah salah satu analisis statistika yang bertujuan mengelompokkan objek-objek berdasarkan kesamaan karakteristik di antara objek-objek tersebut. Objek tersebut akan dikelompokkan ke dalam satu atau beberapa kelompok (cluster) sehingga objek-objek yang berada dalam satu kelompok akan mempunyai kemiripan satu dengan yang lain[1]. Analisis cluster merupakan analisis yang bertujuan untuk mengelompokkan data (objek) yang didasarkan hanya pada informasi yang ditemukan dalam data yang menggambarkan objek tersebut dan hubungan di antaranya. Tujuannya adalah agar objek-objek yang bergabung dalam sebuah kelompok merupakan objek-objek yang mirip (atau berhubungan) satu sama lain dan berbeda (atau tidak berhubungan) dengan objek dalam kelompok yang lain. Lebih besar kemiripannya (homogenitas) dalam kelompok dan lebih besar perbedaannya di antara kelompok lainnya [1]. Potensi clustering adalah dapat digunakan untuk mengetahui struktur dalam data yang dapat dipakai lebih lanjut dalam berbagai aplikasi secara luas seperti klasifikasi, pengolahan gambar, dan pengenalan pola [5].

Ada beberapa metode yang digunakan dalam analisis Cluster, salah satunya metode K-Means. K-Means clustering merupakan salah satu metode clustering data mining menggunakan konsep descriptive model. Metode K-means dapat digunakan untuk menjelaskan algoritma dalam penentuan suatu objek kedalam klaster tertentu berdasarkan rataan terdekat [6]. Cluster Analysis merupakan salah satu metode objek mining yang bersifat tanpa latihan (unsupervised analysis), sedangkan K-Means Cluster Analysis merupakan salah satu metode cluster analysis non hirarki yang berusaha untuk mempartisi objek yang ada ke dalam satu atau lebih cluster atau kelompok objek berdasarkan karakteristiknya, sehingga objek yang mempunyai karakteristik yang sama dikelompokan dalam satu cluster yang sama dan objek yang mempunyai karakteristik yang berbeda dikelompokan ke dalam cluster yang lain [7].

Metode ini telah banyak digunakan dalam berbagai penelitian, seperti yang pernah dilakukan oleh [8], Kesulitan dalam menentukan wilayah mana yang mengalami tingkat kemiskinan yang paling tinggi dan normal serta wilayah dengan tingkat kemiskinan rendah menjadi sebuah alasan untuk melakukan pengclusteran ini. Metode cluster yang digunakan adalah clustering k-means sebagai salah satu permodelan deskriptif. Hasil cluster yang diperoleh dimana record 3 dan record 9 berada pada cluster 2. Record $1,2,4,5,6,7,8,10,11,12$ berada pada cluster 3 . Tidak ada kota atau kabupaten yang berada pada cluster 1. Metode ini memberikan pengetahuan pengclusteran wilayah yang tersebar di Propinsi Riau, sehingga gambaran yang diperoleh dapat menjadi acuan bagi Pemerintah dalam pelaksanaan dan pengaturan sebuah kebijakan. Kemudian penelitian lain oleh [9], Hasil pengelompokan metode K-Means: klaster 1 beranggotakan 13 kabupaten/kota, klaster 2 beranggotakan 17 kabupaten, klaster 3 beranggotakan 1 kota dan klaster 4 beranggotakan 4 kabupaten. Setelah dilakukan perbandingan antara metode K-Means dan metode Fuzzy C-means dengan menggunakan rasio simpangan baku dalam kelompok dengan antar kelompok diperoleh bahwa K-Means merupakan metode terbaik. Penelitian selanjutnya dilakukan oleh [6], Dengan menggunakan K-Means yang merupakan salah satu metode pengklasteran yang paling banyak digunakan sebagai alternative metoda klaster, Hal ini dikarenakan memiliki ketepatan yang lebih tinggi jika dibandingkan dengan metode Hirarki. Metoda K -Means dapat digunakan untuk menjelaskan algorima dalam penentuan suatu objek ke dalam klaster tertentu berdasarkan rataan terdekat dan mudah diimplementasikan dan berdasarkan hasil, kluster pertama terdiri $8 \mathrm{Kab} /$ kota,dan kluster kedua terdiri dari $19 \mathrm{Kab} /$ kota dengan nilai CCR sebesar $96.3 \%$ dan APER sebesar 3,7\% ini menunjukkan bahwa klasifikasi yang terbentuk memiliki tingkat ketepatan yang sangat tinggi juga merupakan pengklasteran secara partitioning yang memisahkan ke dalam kelompok yang berbeda. Berikutnya penelitian yang dilakukan [10], Pengolahan data dengan menggunakan metode clustering dengan algoritma K-Means yakni usia, jenis kendaraan dan jenis pelanggaran. Data kemudian ditransformasi untuk menentukan jarak pengelompokan kemudian diproses dengan tools Matlab dan menghasilkan pusat/cluster antar variable. Dengan pengelompokan objek diperoleh hasil yakni usia diantara 17 sampai dengan 37 tahun, yang melakukan pelanggaran dengan tidak menggunakan sefty belt dan melanggar rambu lalu lintas lebih banyak menggunakan sepeda motor dan mobil.

\section{METODE PENELITIAN}

Metode yang digunakan dalam penelitian ini menggunakan metode K-Means Clustering. Objek pada penelitian ini menggunakan data yang dipublikasi oleh BPS (Badan Pusat Statistik) tentang Data dan Informasi Kemiskinan Kabupaten/Kota tahun 2018. Data dikelompokan dengan clustering dengan metode K-Means. Setelah cluster terbentuk, dilakukan analisa terhadap hasil clustering dengan mengambil nilai rata-rata indikator kemiskinan terendah dan tertinggi dari setiap cluster.

\section{A. Knwoledge Discovery In Database (KDD)}

KDD adalah salah satu metode yang dapat digunakan untuk memperoleh pengetahuan yang berasal dari database yang tersedia. Untuk lebih jelasnya, berikut gambaran dari metode KDD [11].

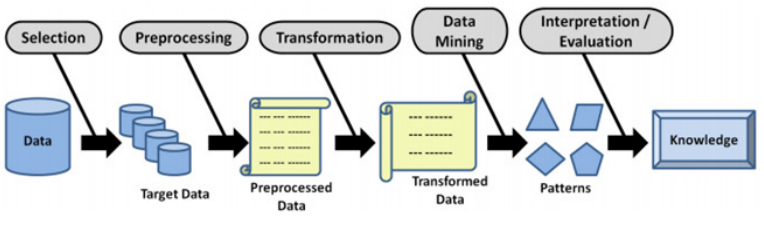

Gambar 1. Metode Knwoledge Discovery In Database

ISSN : 2301-7988

E-ISSN : 2581-0588

DOI : $10.32736 /$ sisfokom.v8i2.653 


\section{Selection}

Digunakan untuk menentukan variabel yang akan diambil agar tidak ada kesamaan dan terjadi perulangan yang tidak diperlukan dalam pengolahan data.

2. Prepocessing

Dalam tahapan ini terdapat 2 tahapan yaitu:

a.Data Cleaning

Mengilangkan data yang tidak diperlukan seperti menghilangkan missing value, noise data dan menangani data yang tidak konsisten dan relevan.

b.Data Integration

Dilakukan terhadap atribut-atribut yang mengidentifikasikan entitas yang unik.

\section{Transformation}

Merubah data sesuai dengan pengolahan data mining karena beberapa metode pada data mining memerlukan format khusus sebelum dapat diproses.

\section{Data mining}

Proses utama pada metode yang digunakan untuk mendapatkan pengetahuan baru dari data yang telah diproses. Pada penelitian ini teknik clustering yang digunakan yaitu metode K-Means.

\section{Evaluation/Interpretation}

Mengidentifikasi pola - pola yang menarik ke dalam knwoledge base yang di identifikasi. Pada tahap ini, menghasilkan pola - pola khas maupun model prediksi yang di evaluasi untuk menilai kajian yang ada telah memenuhi target yang diharapkan.

\section{Knowledge}

Pola-pola yang dihasilkan akan dipresentasikan kepada pengguna. Pada tahapan ini pengetahuan baru yang dihasilkan dapat dipahami oleh semua orang yang akan dijadikan acuan pengambilan keputusan.

\section{B. Proses Algoritma K-Means}

Dasar Algoritma K-Means adalah sebagai berikut [3]:

1. Tentukan nilai $\mathrm{k}$ sebagai jumlah klaster yang ingin dibentuk.

2. Bangkitkan $\mathrm{k}$ centroid (titik pusat klaster) awal secara random/acak, kemudian untuk menghitung centroid cluster $\mathrm{k}-\mathrm{I}$ berikutnya, digunakan rumus sebagai berikut :

$$
v=\sqrt{\frac{\sum_{i}^{k}=1 *}{n}}
$$

Dimana :

i $: 1,2,3, \ldots \mathrm{n}$

$v$ : centroid pada cluster

$x_{i}$ : objek ke-i

$\mathrm{n}$ : banyaknya objek/jumlah objek yang menjadi anggota cluster.
3. Hitung jarak setiap data ke masing-masing centroid menggunakan rumus [3]:

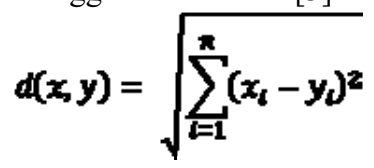

Ket :

dij : Jarak objek antara objek $\mathrm{x}$ dan $\mathrm{y}$

n : Jumlah Atribut

$\mathrm{Xi}$ : Objek Data

Yi : Data Cluster

4. Kelompokkan setiap data berdasarkan jarak terdekat antara data dengan centroidnya (C) [3].

5. Melakukan pengulangan/iterasi dan menentukan posisi centroid baru dengan menggunakan persamaan.

Kembali ke langkah 3 jika posisi centroid baru dengan centroid lama tidak sama.

\section{HASIL DAN PEMBAHASAN}

Data penelitian yang digunakan didapat dari situs resmi Badan Pusat Statistik yaitu https://www.bps.go.id/publication.html. Data yang dipilh adalah data yang diterbitkan pada tahun 2018 tentang kemiskinan. Data yang diolah dalam clustering adalah data kemiskinan Kabupaten/Kota di Jawa Barat yang merupakan bagian dari publikasi Data dan Informasi Kemiskinan Kabupaten/Kota tahun 2018.

Variabel-variabel yang digunakan pada penelitian berdasar dari 13 indikator kemiskinan yang berada pada sektor ekonomi, sumber daya manusia, pendidikan, dan kesehatan yang terdapat pada kabupaten/ kota. Adapun indikator tersebut berupa (dalam satuan \%) : Presentase Penduduk Miskin, Presentase penduduk miskin usia 15 keatas tamat pendidikan SLTA + , Presentase penduduk miskin usia 15 keatas tamat pendidikan SD/SLTP, Presentase penduduk miskin usia 15 keatas tamat pendidikan < SD, Angka Melek Huruf usia 1555th, Angka Partisipasi Sekolah Penduduk Miskin usia 1315th, Penduduk Miskin Usia 15 Tahun ke Atas Tidak Bekerja (termasuk pengangguran dan bukan angkatan kerja), Penduduk Miskin Usia 15 Tahun ke Atas Bekerja di Sektor Informal, Penduduk Miskin Usia 15 Tahun ke Atas Bekerja di Sektor Formal, Persentase Pengeluaran Perkapita untuk Makanan Menurut Kabupaten/Kota dan Status Miskin, Persentase Rumah Tangga Miskin yang Menggunakan Air Layak, Persentase Rumah Tangga Miskin yang Menggunakan Jamban Sendiri/Bersama, Persentase Rumah Tangga Miskin yang Menerima Beras Miskin (Raskin)/Beras Sejahtera (Rastra).

\subsection{Data Cleaning}

Pada tahapan ini, dilakukan pemberian nilai " 0 ” (nol) pada data yang memiliki nilai value "null". Hal ini bertujuan untuk memudahkan proses penghitungan clustering.

ISSN : 2301-7988

E-ISSN : 2581-0588

DOI $\quad: 10.32736 /$ sisfokom.v8i2.653 


\subsection{Transformation}

Pada tahapan ini dilakukan perubahan nilai x1 sampai $\mathrm{x} 13$ pada label atribut/variabel. Seperti terlihat berikut :

X1 : Presentase Penduduk Miskin

$\mathrm{X} 2$ : Presentase penduduk miskin usia 15 keatas tamat pendidikan SLTA +

X3 : Presentase penduduk miskin usia 15 keatas tamat pendidikan SD/SLTP

X4 : Presentase penduduk miskin usia 15 keatas tamat pendidikan $<$ SD

X5 : Angka Melek Huruf usia 15-55 th

X6 : Angka Partisipasi Sekolah Penduduk Miskin usia 13-15 th

X7 : Penduduk Miskin Usia 15 Tahun ke Atas Tidak Bekerja *)
X8: Penduduk Miskin Usia 15 Tahun ke Atas Bekerja di Sektor Informal

X9 : Penduduk Miskin Usia 15 Tahun ke Atas Bekerja di Sektor Formal

X10 : Persentase Pengeluaran Perkapita untuk Makanan Menurut Kabupaten/Kota dan Status Miskin

X11 : Persentase Rumah Tangga Miskin yang Menggunakan Air Layak

X12 : Persentase Rumah Tangga Miskin yang Menggunakan Jamban Sendiri/Bersama

X13 : Persentase Rumah Tangga Miskin yang Menerima Beras Miskin (Raskin)/Beras Sejahtera (Rastra)

Hasil dari tahapan ini dapat dilihat pada tabel 1 berikut:

Tabel 1.Tabel Transformation

\begin{tabular}{|c|c|c|c|c|c|c|c|c|c|c|c|c|c|}
\hline & & & & & & & & & & & & & \\
\hline Kota/Kabupaten & $\mathbf{x 1}$ & $\mathrm{x} 2$ & $\mathrm{x3}$ & $x 4$ & $\mathrm{x5}$ & $\mathrm{x6}$ & $\mathbf{x} 7$ & $\mathbf{x 8}$ & $\mathbf{x 9}$ & $\mathbf{x 1 0}$ & $\mathbf{x 1 1}$ & $\mathbf{x 1 2}$ & $\mathrm{x13}$ \\
\hline Bogor & 7,14 & 9,55 & 65,25 & 25,20 & 99,29 & 74,58 & 48,34 & 31,34 & 20,33 & 74,51 & 38,17 & 51,15 & 70,36 \\
\hline Sukabumi & 6,76 & 4,56 & 69,66 & 25,78 & 100,00 & 83,70 & 50,86 & 37,77 & 11,36 & 74,87 & 44,05 & 58,00 & 68,46 \\
\hline Cianjur & 9,81 & 4,66 & 62,00 & 33,34 & 100,00 & 62,98 & 46,99 & 38,97 & 14,04 & 70,86 & 36,60 & 68,23 & 78,76 \\
\hline Bandung & 6,65 & 15,35 & 76,87 & 7,77 & 99,51 & 85,21 & 48,27 & 29,64 & 22,09 & 70,98 & 66,61 & 80,00 & 74,01 \\
\hline Garut & 9,27 & 10,28 & 68,08 & 21,64 & 99,49 & 81,39 & 41,69 & 45,51 & 12,80 & 76,98 & 55,88 & 73,16 & 63,41 \\
\hline Tasikmalaya & 9,85 & 6,70 & 77,29 & 16,01 & 98,92 & 83,12 & 44,19 & 45,23 & & 71,78 & 42,80 & 56,54 & 70,15 \\
\hline Ciamis & 7,22 & 11,74 & 62,37 & 25,89 & 100,00 & 100,00 & 48,79 & 30,74 & 2 & 08 & 56,18 & 10 & 73,53 \\
\hline Kuningan & 12,22 & \begin{tabular}{|l|}
7,89 \\
\end{tabular} & 69,23 & 22,87 & 99,45 & 80,89 & 45,27 & 40,64 & 14,09 & 7 & 80,09 & 92,68 & 376,08 \\
\hline Cirebon & 10,70 & 16,09 & 51,07 & 32,84 & 99,43 & 100,00 & 52,24 & 29,17 & 18,59 & 72,15 & 67,26 & 73,15 & 93,48 \\
\hline Majalengka & 10,79 & 10,40 & 58,31 & 31,29 & 98,31 & 88,40 & 40,13 & 45,38 & 14,49 & 72,12 & 65,58 & 78,23 & 78,11 \\
\hline Sumedang & 9,76 & 11,44 & 77,67 & 10,89 & 100,00 & 90,69 & 44,52 & 35,89 & 19,58 & 64,45 & 73,16 & 79,71 & 79,28 \\
\hline Indramayu & 11,89 & 11,64 & 45,82 & 42,54 & 98,08 & 94,61 & 52,48 & 34,45 & 13,07 & 70,54 & 82,14 & 90,47 & 53,95 \\
\hline Subang & 8,67 & 9,33 & 67,08 & 23,59 & 100,00 & 87,26 & 55,48 & 26,98 & 17,55 & 72,80 & 48,65 & 77,68 & 68,47 \\
\hline Purwakarta & 7,99 & 4,04 & 59,56 & 36,40 & 99,30 & 91,93 & 50,25 & 36,38 & 13,36 & 67,60 & 44,69 & 64,38 & 62,62 \\
\hline Karawang & 8,06 & 7,61 & 49,11 & 43,27 & 98,00 & 92,52 & 52,09 & 33,32 & 14,59 & 73,23 & 75,15 & 62,96 & 88,35 \\
\hline Bekasi & 4,37 & 14,90 & 61,37 & 23,74 & 99,71 & 100,00 & 64,07 & 17,08 & 18 & 67,53 & 86,69 & 80,34 & 60,94 \\
\hline Bandung Barat & 10,06 & 10,68 & 71,45 & 17,87 & 100,00 & 91,88 & 51,91 & 28, & 20 & & 67,94 & 83 & 63,42 \\
\hline Pangandaran & 8,12 & 7,87 & 76,62 & 15,50 & 100,00 & 61,14 & 36,82 & 40,77 & 22,40 & 72,64 & 71,28 & 54,99 & 63,84 \\
\hline Kota Bogor & 5,93 & 35,38 & 45,71 & 18,90 & 98,34 & 100,00 & 45,81 & 17,51 & 36,69 & 69,29 & 68,88 & 83,72 & 4,76 \\
\hline Kota Sukabumi & 7,12 & 19,25 & 77,11 & 3,64 & 100,00 & 100,00 & 61,83 & 20,19 & 17,98 & 75,83 & 58,01 & 89,99 & 4,71 \\
\hline Kota Bandung & 3,57 & 17,95 & 61,62 & 20,43 & 98,02 & 80,75 & 54,90 & 15,93 & 29,17 & 61,89 & 77,50 & 90,74 & 40,00 \\
\hline Kota Cirebon & 8,88 & 32,91 & 50,60 & 16,49 & 100,00 & 77,03 & 47,83 & 22,01 & 30,16 & 69,43 & 88,74 & 100,00 & 0,00 \\
\hline Kota Bekasi & 4,11 & 31,43 & 53,56 & 15,01 & 100,00 & 100,00 & 42,32 & 20,46 & 37,22 & 62,08 & 61,19 & 96,67 & 4,05 \\
\hline Kota Depok & 2,14 & 43,60 & 52,13 & 4,27 & 100,00 & 100,00 & 59,62 & 17,51 & 22,86 & 54,55 & 77,07 & 100,00 & 5,39 \\
\hline Kota Cimahi & 4,94 & 22,08 & 70,66 & 7,26 & 100,00 & 100,00 & 49,23 & 26,43 & 24,34 & 71,93 & 63,96 & 84,32 & 0,00 \\
\hline $\begin{array}{l}\text { Kota } \\
\text { Tasikmalaya }\end{array}$ & 12,71 & 14,80 & 76,11 & 9,09 & 100,00 & 82,15 & 36,82 & 32,81 & 30,37 & 73,56 & 70,39 & 78,03 & 0,00 \\
\hline Kota Banjar & 5,70 & 26,61 & 53,32 & 20,07 & 100,00 & 100,00 & 46,12 & 28,48 & 25,40 & 78,36 & 87,46 & 56,54 & 12,64 \\
\hline
\end{tabular}

\subsection{Proses Training}

1. Iterasi 1

Tentukan K jumlah pusat cluster secara acak. Pada percobaan pertama ini ditentukan 5 data secara acak sebagai titik pusat awal untuk perhitungan jarak dari seluruh kelompok yang akan dibentuk.

Jumlah cluster $=5$ (diambil secara acak)

Jumlah data $=27$

Jumlah atribut $=13$

ISSN $\quad: 2301-7988$

E-ISSN : 2581-0588

DOI : $10.32736 /$ sisfokom.v8i2.653 
Data acak tersebut dapat dilihat pada tabel berikut ini:

Tabel 2.Tabel Centroid Cluster Iterasi 1

\begin{tabular}{|c|c|c|c|c|c|c|c|c|c|c|c|c|c|c|}
\hline Kota/Kabupaten & $\mathbf{x 1}$ & $\mathbf{x 2}$ & $\mathbf{x 3}$ & $\mathbf{x 4}$ & $\mathbf{x 5}$ & $\mathbf{x 6}$ & $\mathbf{x 7}$ & $\mathbf{x 8}$ & $\mathbf{x 9}$ & $\mathbf{x 1 0}$ & $\mathbf{x 1 1}$ & $\mathbf{x 1 2}$ & $\mathbf{x 1 3}$ & Cluster \\
\hline Sukabumi & 6,76 & 4,56 & 69,66 & 25,78 & 100 & 83,7 & 50,86 & 37,77 & 11,36 & 74,87 & 44,05 & 58 & 68,46 & $\mathbf{C 1}$ \\
\hline Kota Bekasi & 4,11 & 31,43 & 53,56 & 15,01 & 100 & 100 & 42,32 & 20,46 & 37,22 & 62,08 & 61,19 & 96,67 & 4,05 & C2 \\
\hline Kota Banjar & 5,7 & 26,61 & 53,32 & 20,07 & 100 & 100 & 46,12 & 28,48 & 25,4 & 78,36 & 87,46 & 56,54 & 12,64 & C3 \\
\hline Majalengka & 10,79 & 10,4 & 58,31 & 31,29 & 98,31 & 88,4 & 40,13 & 45,38 & 14,49 & 72,12 & 65,58 & 78,23 & 78,11 & C4 \\
\hline Kuningan & 12,22 & 7,89 & 69,23 & 22,87 & 99,45 & 80,89 & 45,27 & 40,64 & 14,09 & 75,34 & 80,09 & 92,68 & 76,08 & C5 \\
\hline
\end{tabular}

Dari Tabel 2 dapat dilihat bahwa masing-masing pusat cluster memiliki jarak antar pusat cluster yang terlihat pada Tabel 3.

Tabel 3.Tabel Jarak Antar Pusat Cluster Iterasi 1
\begin{tabular}{|c|c|c|}
\hline C1 & C 2 & 92,26375 \\
\hline C1 & C 3 & 79,83183 \\
\hline C1 & C4 & 37,29338 \\
\hline C1 & C5 & 51,61937 \\
\hline C2 & C 3 & 53,93747 \\
\hline C2 & C4 & 89,43907 \\
\hline C2 & C5 & 89,33609 \\
\hline C3 & C4 & 79,32114 \\
\hline C3 & C5 & 81,79295 \\
\hline C4 & C5 & 27,18578 \\
\hline & BCV & 682,0208 \\
\hline
\end{tabular}

1. Hitung jarak tiap data dengan masing-masing cluster pusat dengan menggunakan persamaan (3) yaitu persamaan Euclidean Distance.

\begin{tabular}{|c|c|c|c|c|c|}
\hline Kota/Kabupaten & C1 & $\mathrm{C2}$ & C3 & C4 & $\mathbf{C 5}$ \\
\hline Bogor & 18,49 & 94,702 & 83,38 & 46,26 & 61,155 \\
\hline Sukabumi & 0 & 92,264 & 79,83 & 37,29 & 51,619 \\
\hline Cianjur & 29,33 & 102,47 & 97,53 & 41,6 & 54,967 \\
\hline Bandung & 41,5 & 81,91 & 76,65 & 36,67 & 30,847 \\
\hline Garut & 28,43 & 96,956 & 87,17 & 20,45 & 32,852 \\
\hline Tasikmalaya & 16,92 & 96,09 & 84,5 & 41,49 & 53,883 \\
\hline Ciamis & 27,05 & 83,763 & 71,92 & 28,86 & 45,007 \\
\hline Kuningan & 51,62 & 89,336 & 81,79 & 27,19 & 0 \\
\hline Cirebon & 48,37 & 99,064 & 87,44 & 30,23 & 43,855 \\
\hline Majalengka & 37,29 & 89,439 & 79,32 & 0 & 27,186 \\
\hline Sumedang & 45,24 & 88,129 & 80,48 & 32,5 & 26,983 \\
\hline Indramayu & 61,64 & 72,276 & 63,5 & 40,1 & 41,862 \\
\hline Subang & 25,29 & 79,456 & 76,97 & 33,31 & 40,514 \\
\hline Purwakarta & 20,47 & 83,581 & 74,93 & 34,1 & 52,629 \\
\hline Karawang & 47,36 & 103,91 & 84,32 & 31,3 & 46,247 \\
\hline Bekasi & 59,48 & 73,591 & 61,07 & 49,23 & 44,224 \\
\hline Bandung Barat & 40,39 & 71,349 & 67,19 & 33,19 & 29,22 \\
\hline Pangandaran & 42,2 & 93,814 & 74,81 & 47,07 & 48,082 \\
\hline Kota Bogor & 91,02 & 19,973 & 40,19 & 88,46 & 90,032 \\
\hline Kota Sukabumi & 82,36 & 42,853 & 57,6 & 89,79 & 85,139 \\
\hline Kota Bandung & 90,29 & 34,814 & 49,72 & 90,01 & 84,571 \\
\hline Kota Cirebon & 101,9 & 38,557 & 52,87 & 94,29 & 87,198 \\
\hline Kota Bekasi & 92,26 & 0 & 53,94 & 89,44 & 89,336 \\
\hline Kota Depok & 102,2 & 33,247 & 58,97 & 97,53 & 93,223 \\
\hline Kota Cimahi & 83,69 & 31,04 & 45,01 & 87,85 & 85,546 \\
\hline Kota Tasikmalaya & 82,64 & 44,974 & 47,04 & 86,15 & 82,37 \\
\hline
\end{tabular}

ISSN : 2301-7988

E-ISSN : 2581-0588

DOI : $10.32736 /$ sisfokom.v8i2.653 


\section{\begin{tabular}{l|l|r|} 
Kota Banjar & 79,83 & 53,937 \\
\hline
\end{tabular}}

Anggota dipilih dari yang terkecil diantara 5 cluster jika terkecil pada bagian $\mathrm{C} 1$ maka termasuk sebagai anggota $\mathrm{C} 1$ yaitu sebanyak 8 data, jika terkecil pada bagian $\mathrm{C} 2$ maka termasuk sebagai anggota $\mathrm{C} 2$ yaitu sebanyak 8 data, jika terkecil pada bagian C3 maka termasuk sebagai anggota C3 yaitu sebanyak 1 data, jika terkecil pada bagian $\mathrm{C} 4$ maka termasuk sebagai anggota $\mathrm{C} 4$ yaitu sebanyak 4 data, dan jika terkecil pada bagian C5 maka termasuk sebagai anggota C5 yaitu sebanyak 6 data. Berikut adalah rasio pada iterasi ke 1 yang ditampilkan pada tabel 5 . \begin{tabular}{|l|l|l|}
0 & 79,32 & 81,793 \\
\hline
\end{tabular}

\begin{tabular}{|c|c|}
\hline Iterasi & Rasio \\
\hline 1 & 0,0303 \\
\hline 0 & 0,0000 \\
\hline
\end{tabular}

Karena rasio sebelumnya belum ada maka iterasi dilanjutkan.

3. Lakukan iterasi ke 2

Tentukan posisi centroid baru dengan cara menghitung rata-rata dari data-data yang ada pada centroid yang sama atau anggota yang sama. Hasil perhitungan tersebut dapat dilihat pada tabel 6 sebagai berikut:

Tabel 6.Tabel Centroid Cluster Iterasi 2

\begin{tabular}{|c|c|c|c|c|c|c|c|c|c|c|c|c|c|}
\hline $\begin{array}{c}\text { Kota/Ka } \\
\text { bupaten }\end{array}$ & $\mathbf{x 1}$ & $\mathbf{x 2}$ & $\mathbf{x 3}$ & $\mathbf{x 4}$ & $\mathbf{x 5}$ & $\mathbf{x 6}$ & $\mathbf{x 7}$ & $\mathbf{x 8}$ & $\mathbf{x 9}$ & $\mathbf{x 1 0}$ & $\mathbf{x 1 1}$ & $\mathbf{x 1 2}$ & $\mathbf{x 1 3}$ \\
\hline $\mathrm{C} 1$ & 8,195 & 7,30625 & $\begin{array}{c}67,4787 \\
5\end{array}$ & $\begin{array}{c}25,2137 \\
5\end{array}$ & $\begin{array}{c}99,6887 \\
5\end{array}$ & $\begin{array}{c}80,5887 \\
5\end{array}$ & 47,715 & 36,0225 & 16,26 & 72,0175 & 47,8025 & 61,88375 & 69,52375 \\
\hline $\mathrm{C} 2$ & 6,175 & 27,175 & 60,9375 & $\begin{array}{c}11,8862 \\
5\end{array}$ & $\begin{array}{c}99,545 \\
\text { C }\end{array}$ & $\begin{array}{c}92,4912 \\
5\end{array}$ & 49,795 & 21,60625 & $\begin{array}{c}28,5987 \\
5\end{array}$ & 67,32 & 70,7175 & 90,43375 & 2,36375 \\
\hline $\mathrm{C} 4$ & 5,70 & 26,61 & 53,32 & 20,07 & 100,00 & 100,00 & 46,12 & 28,48 & 25,40 & 78,36 & 87,46 & 56,54 & 12,64 \\
\hline $\mathrm{C} 5$ & 8,00 & 9,98 & 55,33 & 34,69 & 98,47 & 89,23 & 46,60 & 39,67 & 13,74 & 73,22 & 69,69 & 76,21 & 75,96 \\
\hline
\end{tabular}

Kemudian hitung jarak tiap data dengan masing-masing cluster pusat. Perhitungannya sama dengan tahap perhitungan pada iterasi 1. Hasil dari perhitungan tersebut ditunjukkan pada tabel 7 berikut ini:

\begin{tabular}{|c|c|c|c|c|c|}
\hline Kota/Kabupaten & C1 & $\mathrm{C2}$ & $\mathrm{C3}$ & C4 & $\overline{C 5}$ \\
\hline Bogor & 17,35427 & 90,94656 & 83,38003 & 46,71114 & 50,69596 \\
\hline Sukabumi & 9,992208 & 87,2169 & 79,83183 & 37,8485 & 42,22242 \\
\hline Cianjur & 26,12258 & 99,39771 & 97,52926 & 44,02959 & 52,84952 \\
\hline Bandung & 35,48399 & 76,45527 & 76,65068 & 38,09731 & 18,33138 \\
\hline Garut & 23,91553 & 92,90553 & 87,16968 & 26,91922 & 31,48227 \\
\hline Tasikmalaya & 19,3538 & 90,89865 & 84,49798 & 45,51351 & 46,34744 \\
\hline Ciamis & 23,72304 & 81,41455 & 71,91679 & 26,92891 & 27,74649 \\
\hline Kuningan & 45,84945 & 83,16861 & 81,79295 & 28,2774 & 22,97275 \\
\hline Cirebon & 44,04547 & 97,65101 & 87,44163 & 25,79292 & 32,13113 \\
\hline Majalengka & 31,7082 & 86,59037 & 79,32114 & 11,12619 & 26,8753 \\
\hline Sumedang & 39,56233 & 83,08648 & 80,48317 & 35,16963 & 17,30782 \\
\hline Indramayu & 57,24714 & 68,29437 & 63,49521 & 33,16229 & 41,01748 \\
\hline Subang & 21,15202 & 75,89414 & 76,96723 & 32,01374 & 27,63656 \\
\hline Purwakarta & 20,62482 & 81,11431 & 74,93207 & 32,65785 & 42,26717 \\
\hline Karawang & 44,07869 & 100,2761 & 84,31773 & 23,72543 & 39,22283 \\
\hline Bekasi & 55,39209 & 66,7725 & 61,06984 & 41,65575 & 29,35907 \\
\hline Bandung Barat & 34,95437 & 65,88984 & 67,18771 & 31,50248 & 13,72137 \\
\hline Pangandaran & 36,97218 & 85,18689 & 74,80512 & 48,91117 & 46,83788 \\
\hline Kota Bogor & 87,01848 & 23,7168 & 40,18994 & 85,31647 & 80,56594 \\
\hline Kota Sukabumi & 81,49393 & 30,80657 & 57,60356 & 87,68728 & 76,76383 \\
\hline Kota Bandung & 86,41437 & 21,10228 & 49,7163 & 86,37106 & 79,07475 \\
\hline Kota Cirebon & 96,89338 & 28,98875 & 52,86781 & 91,2533 & 85,16302 \\
\hline Kota Bekasi & 88,08449 & 20,84763 & 53,93747 & 87,90474 & 81,16948 \\
\hline Kota Depok & 98,28889 & 30,47247 & 58,97147 & 94,5402 & 84,63077 \\
\hline
\end{tabular}

ISSN : 2301-7988

E-ISSN : 2581-0588

DOI : $10.32736 /$ sisfokom.v8i2.653 


\begin{tabular}{|c|c|c|c|c|c|}
\hline Kota/Kabupaten & C1 & C2 & C3 & C4 & C5 \\
\hline Kota Cimahi & 81,82797 & 18,75121 & 45,01068 & 86,26377 & 77,70524 \\
\hline Kota Tasikmalaya & 79,67742 & 32,19497 & 47,044 & 85,80357 & 78,81106 \\
\hline Kota Banjar & 77,47849 & 43,70011 & 0 & 75,03407 & 72,67131 \\
\hline
\end{tabular}

Anggota dipilih dari yang terkecil diantara 5 cluster jika terkecil pada bagian $\mathrm{C} 1$ maka termasuk sebagai anggota $\mathrm{C} 1$ yaitu sebanyak 9 data, jika terkecil pada bagian C2 maka termasuk sebagai anggota $\mathrm{C} 2$ yaitu sebanyak 8 data, jika terkecil pada bagian $\mathrm{C} 3$ maka termasuk sebagai anggota $\mathrm{C} 3$ yaitu sebanyak 1 data, jika terkecil pada bagian $\mathrm{C} 4$ maka termasuk sebagai anggota $\mathrm{C} 4$ yaitu sebanyak 4 data, dan jika terkecil pada bagian C5 maka termasuk sebagai anggota C5 yaitu sebanyak 5 data. Rasio pada iterasi ke 2 yang ditampilkan pada tabel 8 berikut:
Tabel 8.Tabel Perhitungan Rasio Iterasi 2

\begin{tabular}{|c|c|}
\hline Iterasi & Ratio \\
\hline 1 & 0,0303 \\
\hline 2 & 0,0403 \\
\hline
\end{tabular}

Karena hasil rasio iterasi ke-2 tidak sama dengan iterasi ke-1, maka perlu dilakukan kembali perhitungan ke iterasi ke3 dan seterusnya sampai mendapatkan hasil yang sama.

\section{Lakukan iterasi ke 3}

Tentukan posisi centroid baru dengan cara menghitung ratarata dari data-data yang ada pada centroid yang sama atau anggota yang sama. Hasil perhitungan tersebut dapat dilihat pada tabel 9 sebagai berikut:

Tabel 9.Tabel Centroid Cluster Iterasi 3

\begin{tabular}{|c|c|c|c|c|c|c|c|c|c|c|c|c|c|}
\hline Kota/Kabupaten & $\mathbf{x 1}$ & $\mathbf{x 2}$ & x3 & $\mathrm{x4}$ & $\mathrm{x5}$ & $\mathrm{x6}$ & $\mathbf{x} 7$ & $\mathbf{x 8}$ & $\mathbf{x 9}$ & $\mathbf{x 1 0}$ & $\mathbf{x 1 1}$ & $\mathbf{x 1 2}$ & $\mathbf{x 1 3}$ \\
\hline C1 & 8,31 & 7,64 & 67,55 & 24,82 & 99,67 & 80,68 & 47,05 & 37,08 & 15,88 & 72,57 & 48,70 & 63,14 & 71,07 \\
\hline $\mathrm{C} 2$ & 6,18 & 27,18 & 60,94 & 11,89 & 99,55 & 92,49 & 49,80 & 21,61 & 28,60 & 67,32 & 70,72 & 90,43 & 2,36 \\
\hline C3 & 5,7 & 26,61 & 53,32 & 20,07 & 100 & 100 & 46,12 & 28,48 & 25,4 & 78,36 & 87,46 & 56,54 & 12,64 \\
\hline 4 & 0,36 & 1,435 & 51,0775 & 37,485 & 8,455 & 93,8825 & 49,235 & 35,58 & 15,185 & 72,01 & 72,5325 & 76,20 & 78,4725 \\
\hline 5 & 8,612 & 12,052 & 71,318 & 16,628 & 99,734 & 89,734 & 50,808 & 30,26 & 18,93 & 69,248 & 74,898 & 83,188 & 70,74 \\
\hline
\end{tabular}

Kemudian hitung jarak tiap data dengan masing-masing cluster pusat. Perhitungannya sama dengan tahap perhitungan pada iterasi 2. Hasil dari perhitungan tersebut ditunjukkan pada tabel 10 di bawah ini:

Tabel 10.Tabel Perhitungan Euclidean Distance Iterasi 3

\begin{tabular}{|c|c|c|c|c|c|}
\hline Kota/Kabupaten & $\mathbf{C 1}$ & $\mathbf{C 2}$ & $\mathbf{C 3}$ & $\mathbf{C 4}$ & $\mathbf{C 5}$ \\
\hline Bogor & 19,00097 & 90,94656 & 83,38003 & 51,62081 & 52,54524 \\
\hline Sukabumi & 11,04738 & 87,2169 & 79,83183 & 43,83712 & 43,80779 \\
\hline Cianjur & 25,86961 & 99,39771 & 97,52926 & 50,13971 & 54,86069 \\
\hline Bandung & 34,23618 & 76,45527 & 76,65068 & 42,52078 & 15,93271 \\
\hline Garut & 21,25825 & 92,90553 & 87,16968 & 34,59288 & 33,83109 \\
\hline Tasikmalaya & 19,09794 & 90,89865 & 84,49798 & 52,59973 & 46,85527 \\
\hline Ciamis & 23,42669 & 81,41455 & 71,91679 & 28,3257 & 31,71457 \\
\hline Kuningan & 43,95484 & 83,16861 & 81,79295 & 33,41996 & 22,28043 \\
\hline Cirebon & 42,78447 & 97,65101 & 87,44163 & 20,1447 & 38,55736 \\
\hline Majalengka & 29,72676 & 86,59037 & 79,32114 & 18,81589 & 30,52366 \\
\hline Sumedang & 37,96339 & 83,08648 & 80,48317 & 39,23697 & 16,08027 \\
\hline Indramayu & 56,73004 & 68,29437 & 63,49521 & 31,17542 & 42,46111 \\
\hline Subang & 21,03201 & 75,89414 & 76,96723 & 35,9787 & 29,18248 \\
\hline Purwakarta & 21,64428 & 81,11431 & 74,93207 & 36,45115 & 44,75014 \\
\hline Karawang & 43,16796 & 100,2761 & 84,31773 & 18,82027 & 44,70606 \\
\hline Bekasi & 55,19639 & 66,7725 & 61,06984 & 38,76233 & 29,61269 \\
\hline Bandung Barat & 34,30614 & 65,88984 & 67,18771 & 34,75069 & 11,0155 \\
\hline Pangandaran & 36,6101 & 85,18689 & 74,80512 & 55,92061 & 45,28116 \\
\hline Kota Bogor & 87,85293 & 23,7168 & 40,18994 & 85,53445 & 78,82428 \\
\hline Kota Sukabumi & 82,33756 & 30,80657 & 57,60356 & 90,52266 & 72,94569 \\
\hline Kota Bandung & 87,33531 & 21,10228 & 49,7163 & 88,16675 & 75,51328 \\
\hline Kota Cirebon & 97,27826 & 28,98875 & 52,86781 & 92,70783 & 81,90337 \\
\hline Kota Bekasi & 88,79634 & 20,84763 & 53,93747 & 89,08883 & 78,68431 \\
\hline Kota Depok & 98,77434 & 30,47247 & 58,97147 & 94,72277 & 81,81676 \\
\hline
\end{tabular}

ISSN : :2301-7988

E-ISSN : 2581-0588

DOI : $10.32736 /$ sisfokom.v8i2.653 
Jurnal SISFOKOM, Volume 08, Nomor 02, September 2019

\begin{tabular}{|c|c|c|c|c|c|}
\hline Kota/Kabupaten & C1 & C2 & C3 & C4 & C5 \\
\hline Kota Cimahi & 82,66585 & 18,75121 & 45,01068 & 89,13128 & 74,07588 \\
\hline Kota Tasikmalaya & 80,43735 & 32,19497 & 47,044 & 90,2798 & 74,60077 \\
\hline Kota Banjar & 78,2542 & 43,70011 & 0 & 75,8173 & 71,10495 \\
\hline
\end{tabular}

Anggota dipilih dari yang terkecil diantara 5 cluster jika terkecil pada bagian $\mathrm{C} 1$ maka termasuk sebagai anggota $\mathrm{C} 1$ yaitu sebanyak 9 data, jika terkecil pada bagian C2 maka termasuk sebagai anggota $\mathrm{C} 2$ yaitu sebanyak 8 data, jika terkecil pada bagian $\mathrm{C} 3$ maka termasuk sebagai anggota $\mathrm{C} 3$ yaitu sebanyak 1 data, jika terkecil pada bagian $\mathrm{C} 4$ maka termasuk sebagai anggota $\mathrm{C} 4$ yaitu sebanyak 4 data, dan jika terkecil pada bagian C5 maka termasuk sebagai anggota C5 yaitu sebanyak 5 data. Rasio pada iterasi ke 3 yang ditampilkan pada tabel 11 berikut ini:

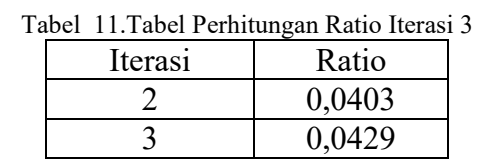

Karena hasil iterasi ke-3 tidak sama dengan iterasi ke-2, maka perlu dilakukan kembali perhitungan ke iterasi ke-4 dan seterusnya sampai mendapatkan hasil yang sama.

3. Lakukan iterasi ke 4

Tentukan posisi centroid baru dengan cara menghitung rata-rata dari data-data yang ada pada centroid yang sama atau anggota yang sama. Hasil perhitungan tersebut dapat dilihat pada tabel 12 sebagai berikut:

Tabel 12.Tabel Centroid Cluster Iterasi 4

\begin{tabular}{|c|c|c|c|c|c|c|c|c|c|c|c|c|c|}
\hline Kota/Kabupaten & $\mathbf{x 1}$ & $\mathbf{x 2}$ & $\mathbf{x 3}$ & $\mathrm{x4}$ & $\mathbf{x 5}$ & $\mathrm{x6}$ & $\mathbf{x} 7$ & $\mathbf{x 8}$ & x9 & $\mathbf{x 1 0}$ & $\mathbf{x 1 1}$ & $\mathbf{x 1 2}$ & $\mathbf{x 1 3}$ \\
\hline $\mathrm{C} 1$ & 8,31 & 7,64 & 67,55 & 24,82 & 99,67 & 80,68 & 47,05 & 37,08 & 15,88 & 72,57 & 48,70 & 63,14 & 71,07 \\
\hline $\mathrm{C} 2$ & 6,18 & 27,18 & 60,94 & 11,89 & 99,55 & 92,49 & 49,80 & 21,61 & 28 & 67,32 & 70,72 & 3 & 2,36 \\
\hline $\mathrm{C} 3$ & 5,70 & 26,61 & 53,32 & 20,07 & 100,00 & 100,00 & 46,12 & 28,48 & 25,40 & 78,36 & 87,46 & 56,54 & 12,64 \\
\hline $\mathrm{C} 4$ & 10,36 & 11,44 & 51,08 & 37,49 & 98,46 & & 49,24 & 35,58 & & 72,01 & 72,53 & & 78,47 \\
\hline $\mathrm{C} 5$ & 8,61 & 12,05 & 71,32 & 16,63 & 99,73 & 89,73 & 50,81 & 30,26 & 18,93 & 69,25 & 74,90 & 83,19 & 70,75 \\
\hline
\end{tabular}

Kemudian hitung jarak tiap data dengan masing-masing cluster pusat. Perhitungannya sama dengan tahap perhitungan pada iterasi 3. Hasil dari perhitungan tersebut ditunjukkan pada tabel 13.

\begin{tabular}{|c|c|c|c|c|c|}
\multicolumn{7}{c}{ Tabel 13 .Tabel Perhitungan Euclidean Distance Iterasi 4 } \\
\hline Kota/Kabupaten & C1 & C2 & C3 & C4 & C5 \\
\hline Bogor & 19,00097 & 90,94656 & 83,38003 & 51,62081 & 52,545237 \\
\hline Sukabumi & 11,04738 & 87,2169 & 79,83183 & 43,83712 & 43,807794 \\
\hline Cianjur & 25,86961 & 99,39771 & 97,52926 & 50,13971 & 54,860686 \\
\hline Bandung & 34,23618 & 76,45527 & 76,65068 & 42,52078 & 15,932706 \\
\hline Garut & 21,25825 & 92,90553 & 87,16968 & 34,59288 & 33,831092 \\
\hline Tasikmalaya & 19,09794 & 90,89865 & 84,49798 & 52,59973 & 46,855266 \\
\hline Ciamis & 23,42669 & 81,41455 & 71,91679 & 28,3257 & 31,714565 \\
\hline Kuningan & 43,95484 & 83,16861 & 81,79295 & 33,41996 & 22,280431 \\
\hline Cirebon & 42,78447 & 97,65101 & 87,44163 & 20,1447 & 38,55736 \\
\hline Majalengka & 29,72676 & 86,59037 & 79,32114 & 18,81589 & 30,523661 \\
\hline Sumedang & 37,96339 & 83,08648 & 80,48317 & 39,23697 & 16,080271 \\
\hline Indramayu & 56,73004 & 68,29437 & 63,49521 & 31,17542 & 42,461113 \\
\hline Subang & 21,03201 & 75,89414 & 76,96723 & 35,9787 & 29,182478 \\
\hline Purwakarta & 21,64428 & 81,11431 & 74,93207 & 36,45115 & 44,750139 \\
\hline Karawang & 43,16796 & 100,2761 & 84,31773 & 18,82027 & 44,706056 \\
\hline Bekasi & 55,19639 & 66,7725 & 61,06984 & 38,76233 & 29,612687 \\
\hline Bandung Barat & 34,30614 & 65,88984 & 67,18771 & 34,75069 & 11,015495 \\
\hline Pangandaran & 36,6101 & 85,18689 & 74,80512 & 55,92061 & 45,281157 \\
\hline Kota Bogor & 87,85293 & 23,7168 & 40,18994 & 85,53445 & 78,824284 \\
\hline Kota Sukabumi & 82,33756 & 30,80657 & 57,60356 & 90,52266 & 72,945691 \\
\hline Kota Bandung & 87,33531 & 21,10228 & 49,7163 & 88,16675 & 75,513279 \\
\hline Kota Cirebon & 97,27826 & 28,98875 & 52,86781 & 92,70783 & 81,903375 \\
\hline
\end{tabular}

ISSN : :2301-7988

E-ISSN : 2581-0588

DOI : 10.32736/sisfokom.v8i2.653 


\begin{tabular}{|c|c|c|c|c|c|}
\hline Kota/Kabupaten & $\mathbf{C 1}$ & $\mathbf{C 2}$ & $\mathbf{C 3}$ & $\mathbf{C 4}$ & $\mathbf{C 5}$ \\
\hline Kota Bekasi & 88,79634 & 20,84763 & 53,93747 & 89,08883 & 78,684315 \\
\hline Kota Depok & 98,77434 & 30,47247 & 58,97147 & 94,72277 & 81,816757 \\
\hline Kota Cimahi & 82,66585 & 18,75121 & 45,01068 & 89,13128 & 74,075882 \\
\hline $\begin{array}{c}\text { Kota } \\
\text { Tasikmalaya }\end{array}$ & 80,43735 & 32,19497 & 47,044 & 90,2798 & 74,600769 \\
\hline Kota Banjar & 78,2542 & 43,70011 & 0 & 75,8173 & 71,104952 \\
\hline
\end{tabular}

Clusterisasi pada data indikator kemiskinan wilayah

Anggota dipilih dari yang terkecil diantara 5 cluster jika terkecil pada bagian $\mathrm{C} 1$ maka termasuk sebagai anggota $\mathrm{C} 1$ yaitu sebanyak 9 data, jika terkecil pada bagian C2 maka termasuk sebagai anggota $\mathrm{C} 2$ yaitu sebanyak 8 data, jika terkecil pada bagian C3 maka termasuk sebagai anggota C3 yaitu sebanyak 1 data, jika terkecil pada bagian $\mathrm{C} 4$ maka termasuk sebagai anggota $\mathrm{C} 4$ yaitu sebanyak 4 data, dan jika terkecil pada bagian C5 maka termasuk sebagai anggota C5 yaitu sebanyak 5 data. Rasio pada iterasi ke 4 yang ditampilkan pada tabel 14 berikut ini:

Tabel 14.Tabel Perhitungan Rasio Iterasi 4
\begin{tabular}{|c|c|}
\hline Iterasi & Rasio \\
\hline 3 & 0,0429 \\
\hline 4 & 0,0429 \\
\hline
\end{tabular}

Iterasi ke 4 dengan iterasi ke-3 hasilnya sudah sama maka tidak perlu lagi melanjutkan ke iterasi ke-5 atau cukup berhenti di iterasi ke-4. provinsi Jawa Barat yang dihitung dengan algoritma k-means di dapatkan hasil 5 cluster. Di dalam 5 cluster tersebut beranggotakan sebagai berikut. Cluster 1 yang memiliki 9 anggota, cluster 2 yang memiliki 8 anggota, cluster 3 yang memiliki 1 anggota, cluster 4 yang memiliki 4 anggota, dan yang terakhir cluster 5 memiliki 5 anggota. Hasil perhitungan tersebut di dapatkan setelah dilakukan sebanyak 4 kali iterasi. Dari setiap cluster yang diperoleh, kemudian dilakukan penghitungan rata-rata dari setiap indikator kemiskinan. Sehingga dapat ditentukan indikator tertinggi dan terendah disetiap cluster. Hal tersebut akan menggambarkan karakteristik dari kelompok atau cluster yang telah dibentuk. Berikut data hasil clustering yang ditampilkan pada tabel 15 .

Tabel 15.Tabel Hasil Clustering

\begin{tabular}{|c|c|c|c|c|c|c|c|c|c|c|c|c|c|c|}
\hline \begin{tabular}{|l|} 
Kota/ \\
Kabupaten
\end{tabular} & $\mathrm{x} 1$ & $\mathrm{x} 2$ & $\mathrm{x} 3$ & $\mathrm{x} 4$ & $\mathrm{x} 5$ & x6 & $\mathrm{x} 7$ & $\mathrm{x} 8$ & x9 & $\mathbf{x 1 0}$ & $\mathbf{x 1 1}$ & $\mathbf{x 1 2}$ & $\mathbf{x 1 3}$ & Cluster \\
\hline Bogor & 7,14 & 9,55 & 65,25 & 25,2 & 99,29 & 74,58 & 48,34 & 31,34 & 20,33 & 74,51 & 38,17 & 51,15 & 70,36 & $\mathrm{C} 1$ \\
\hline Sukabumi & 6,76 & 4,56 & 69,66 & 25,78 & 100 & 83,7 & 50,86 & 37,77 & 11,36 & 74,87 & 44,05 & 58 & 68,46 & $\mathrm{C} 1$ \\
\hline Cianjur & \begin{tabular}{|l|}
9,81 \\
\end{tabular} & 4,66 & 62 & 33,34 & 100 & 62,98 & 46,99 & 38,97 & 14,04 & 70,86 & 36,6 & 68,23 & 78,76 & $\mathrm{C} 1$ \\
\hline Garut & \begin{tabular}{|l|}
9,27 \\
\end{tabular} & 10,28 & 68,08 & 21,64 & 99,49 & 81,39 & 41,69 & 45,51 & 12,8 & 76,98 & 55,88 & 73,16 & 83,41 & $\mathrm{C} 1$ \\
\hline $\begin{array}{l}\text { Tasikmalay } \\
\text { a }\end{array}$ & 9,85 & 6,7 & 77,29 & 16,01 & 98,92 & 83,12 & 44,19 & 45,23 & 10,58 & 71,78 & 42,8 & 56,54 & 70,15 & $\mathrm{C} 1$ \\
\hline Ciamis & 7,22 & 11,74 & 62,37 & 25,89 & 100 & 100 & 48,79 & 30,74 & 20,46 & 71,08 & 56,18 & 64,1 & 73,53 & $\mathrm{C} 1$ \\
\hline Subang & \begin{tabular}{|l|}
8,67 \\
\end{tabular} & 9,33 & 67,08 & 23,59 & 100 & 87,26 & 55,48 & 26,98 & 17,55 & 72,8 & 48,65 & 77,68 & 68,47 & $\mathrm{C} 1$ \\
\hline Purwakarta & 7,99 & 4,04 & 59,56 & 36,4 & 99,3 & 91,93 & 50,25 & 36,38 & 13,36 & 67,6 & 44,69 & 64,38 & 62,62 & $\mathrm{C} 1$ \\
\hline $\begin{array}{l}\text { Pangandara } \\
n\end{array}$ & 8,12 & 7,87 & 76,62 & 15,5 & 100 & 61,14 & 36,82 & 40,77 & 22,4 & 72,64 & 71,28 & 54,99 & 63,84 & $\mathrm{C} 1$ \\
\hline Rata-Rata & 8,31 & 7,64 & 67,55 & 24,82 & 99,67 & 80,68 & 47,05 & 37,08 & 15,88 & 72,57 & 48,70 & 63,14 & 71,07 & \\
\hline Kota Bogor & \begin{tabular}{|l|}
5,93 \\
\end{tabular} & 35,38 & 45,71 & 18,9 & 98,34 & 100 & 45,81 & 17,51 & 36,69 & 69,29 & 68,88 & 83,72 & 4,76 & $\mathrm{C} 2$ \\
\hline \begin{tabular}{|l} 
Kota \\
Sukabumi
\end{tabular} & 7,12 & 19,25 & 77,11 & 3,64 & 100 & 100 & 61,83 & 20,19 & 17,98 & 75,83 & 58,01 & 89,99 & 4,71 & $\mathrm{C} 2$ \\
\hline \begin{tabular}{|l|} 
Kota \\
Bandung
\end{tabular} & 3,57 & 17,95 & 61,62 & 20,43 & 98,02 & 80,75 & 54,9 & 15,93 & 29,17 & 61,89 & 77,5 & 90,74 & 0 & $\mathrm{C} 2$ \\
\hline \begin{tabular}{|l|} 
Kota \\
Cirebon
\end{tabular} & 8,88 & 32,91 & 50,6 & 16,49 & 100 & 77,03 & 47,83 & 22,01 & 30,16 & 69,43 & 88,74 & 100 & 0 & $\mathrm{C} 2$ \\
\hline Kota Bekasi & 4,11 & 31,43 & 53,56 & 15,01 & 100 & 100 & 42,32 & 20,46 & 37,22 & 62,08 & 61,19 & 96,67 & 4,05 & $\mathrm{C} 2$ \\
\hline Kota Depok & 2,14 & 43,6 & 52,13 & 4,27 & 100 & 100 & 59,62 & 17,51 & 22,86 & 54,55 & 77,07 & 100 & 5,39 & $\mathrm{C} 2$ \\
\hline \begin{tabular}{|l} 
Kota \\
Cimahi \\
\end{tabular} & 4,94 & 22,08 & 70,66 & 7,26 & 100 & 100 & 49,23 & 26,43 & 24,34 & 71,93 & 63,96 & 84,32 & 0 & $\mathrm{C} 2$ \\
\hline \begin{tabular}{|l|} 
Kota \\
Tasikmalay
\end{tabular} & 12,71 & 14,8 & 76,11 & 9,09 & 100 & 82,15 & 36,82 & 32,81 & 30,37 & 73,56 & 70,39 & 78,03 & 0 & $\mathrm{C} 2$ \\
\hline
\end{tabular}

ISSN : 2301-7988

E-ISSN : 2581-0588

DOI : $10.32736 /$ sisfokom.v8i2.653 


\begin{tabular}{|l|c|c|c|c|c|c|c|c|c|c|c|c|c|c|}
\hline $\begin{array}{l}\text { Kota/ } \\
\text { Kabupaten }\end{array}$ & $\mathbf{x 1}$ & $\mathbf{x 2}$ & $\mathbf{x 3}$ & $\mathbf{x 4}$ & $\mathbf{x 5}$ & $\mathbf{x 6}$ & $\mathbf{x 7}$ & $\mathbf{x 8}$ & $\mathbf{x 9}$ & $\mathbf{x 1 0}$ & $\mathbf{x 1 1}$ & $\mathbf{x 1 2}$ & $\mathbf{x 1 3}$ & Cluster \\
\hline a & & & & & & & & & & & & & & \\
\hline Rata-Rata & 6,18 & 27,18 & 60,94 & 11,89 & 99,55 & 92,49 & 49,80 & 21,61 & 28,60 & 67,32 & 70,72 & 90,43 & 2,36 & \\
\hline Kota Banjar & 5,7 & 26,61 & 53,32 & 20,07 & 100 & 100 & 46,12 & 28,48 & 25,4 & 78,36 & 87,46 & 56,54 & 12,64 & $\mathrm{C} 3$ \\
\hline Rata-Rata & 5,7 & 26,61 & 53,32 & 20,07 & 100 & 100 & 46,12 & 28,48 & 25,4 & 78,36 & 87,46 & 56,54 & 12,64 & \\
\hline Cirebon & 10,7 & 16,09 & 51,07 & 32,84 & 99,43 & 100 & 52,24 & 29,17 & 18,59 & 72,15 & 67,26 & 73,15 & 93,48 & $\mathrm{C} 4$ \\
\hline Majalengka & 10,79 & 10,4 & 58,31 & 31,29 & 98,31 & 88,4 & 40,13 & 45,38 & 14,49 & 72,12 & 65,58 & 78,23 & 78,11 & $\mathrm{C} 4$ \\
\hline Indramayu & 11,89 & 11,64 & 45,82 & 42,54 & 98,08 & 94,61 & 52,48 & 34,45 & 13,07 & 70,54 & 82,14 & 90,47 & 53,95 & $\mathrm{C} 4$ \\
\hline Karawang & 8,06 & 7,61 & 49,11 & 43,27 & 98 & 92,52 & 52,09 & 33,32 & 14,59 & 73,23 & 75,15 & 62,96 & 88,35 & $\mathrm{C} 4$ \\
\hline Rata-Rata & 10,36 & 11,435 & 51,0775 & 37,485 & 98,455 & 93,8825 & 49,235 & 35,58 & 15,185 & 72,01 & $\begin{array}{c}72,532 \\
5\end{array}$ & 76,202 & 78,4725 & \\
\hline Bandung & 6,65 & 15,35 & 76,87 & 7,77 & 99,51 & 85,21 & 48,27 & 29,64 & 22,09 & 70,98 & 66,61 & 80 & 74,01 & $\mathrm{C} 5$ \\
\hline Kuningan & 12,22 & 7,89 & 69,23 & 22,87 & 99,45 & 80,89 & 45,27 & 40,64 & 14,09 & 75,34 & 80,09 & 92,68 & 76,08 & $\mathrm{C} 5$ \\
\hline Sumedang & 9,76 & 11,44 & 77,67 & 10,89 & 100 & 90,69 & 44,52 & 35,89 & 19,58 & 64,45 & 73,16 & 79,71 & 79,28 & $\mathrm{C} 5$ \\
\hline Bekasi & 4,37 & 14,9 & 61,37 & 23,74 & 99,71 & 100 & 64,07 & 17,08 & 18,85 & 67,53 & 86,69 & 80,34 & 60,94 & $\mathrm{C} 5$ \\
\hline $\begin{array}{l}\text { Bandung } \\
\text { Barat }\end{array}$ & 10,06 & 10,68 & 71,45 & 17,87 & 100 & 91,88 & 51,91 & 28,05 & 20,04 & 67,94 & 67,94 & 83,21 & 63,42 & $\mathrm{C} 5$ \\
\hline Rata-Rata & 8,61 & 12,05 & 71,32 & 16,63 & 99,73 & 89,73 & 50,81 & 30,26 & 18,93 & 69,25 & 74,90 & 83,19 & 70,75 & \\
\hline
\end{tabular}

Tabel 16. Tabel Indikator tertinggi dan terendah

\begin{tabular}{|c|c|c|}
\hline Cluster & Indikator tertinggi & Indikator terendah \\
\hline $\mathrm{c} 1$ & $\mathrm{x} 8$ & $\mathrm{x} 2, \mathrm{x} 6, \mathrm{x} 9, \mathrm{x} 11$ \\
\hline $\mathrm{c} 2$ & $\mathrm{x} 2, \mathrm{x} 9, \mathrm{x} 12$ & $\mathrm{x} 4, \mathrm{x} 8, \mathrm{x} 10, \mathrm{x} 13$ \\
\hline $\mathrm{c} 3$ & $\mathrm{x} 5, \mathrm{x} 6, \mathrm{x} 10, \mathrm{x} 11$ & $\mathrm{x} 1, \mathrm{x} 7, \mathrm{x} 12$ \\
\hline $\mathrm{c} 4$ & $\mathrm{x} 1, \mathrm{x} 4, \mathrm{x} 13$ & $\mathrm{x} 3, \mathrm{x} 5$ \\
\hline $\mathrm{c} 5$ & $\mathrm{x} 3, \mathrm{x} 7$ & - \\
\hline
\end{tabular}

Adapun penjelasannya sebagai berikut:

1. Kelompok 1 terdiri dari Bogor, Sukabumi, Cianjur, Garut, Tasikmalaya, Ciamis, Subang, Purawakarta dan Pangandaran memiliki nilai Penduduk Miskin Usia 15 Tahun ke Atas Bekerja di Sektor Informal tertinggi dan nilai terendahnya di sektor Penduduk miskin usia 15 keatas tamat pendidikan SLTA +, Angka Partisipasi Sekolah Penduduk Miskin usia 13-15 th, Penduduk Miskin Usia 15 Tahun ke Atas Bekerja di Sektor Formal, dan Persentase Rumah Tangga Miskin yang Menggunakan Air Layak.

2. Kelompok 2 terdiri dari Kota Bogor, Kota Sukabumi, Kota Bandung, Kota Cirebon, Kota Bekasi, Kota Depok, Kota Cimahi, Kota Tasikmalaya memiliki nilai tertinggi di sektor penduduk miskin usia 15 keatas tamat pendidikan SD/SLTP, Penduduk Miskin Usia 15 Tahun ke Atas Bekerja di Sektor Formal, dan Persentase Rumah Tangga Miskin yang Menggunakan Jamban Sendiri/Bersama serta memiliki nilai terendahnya di sektor penduduk miskin usia 15 keatas tamat pendidikan $<\mathrm{SD}$, Penduduk Miskin Usia 15 Tahun ke Atas Bekerja di Sektor Informal, Pengeluaran Perkapita untuk Makanan Menurut Kabupaten/Kota dan Status Miskin, dan Rumah Tangga Miskin yang Menerima Beras Miskin (Raskin)/Beras Sejahtera (Rastra).

3. Kelompok 3 adalah Kota Banjar yang memiliki nilai tertinggi di sektor Angka Melek Huruf usia 15-55 th, Angka Partisipasi Sekolah Penduduk Miskin usia 13-15 th,
Pengeluaran Perkapita untuk Makanan Menurut Kabupaten/Kota dan Status Miskin, dan Rumah Tangga Miskin yang Menggunakan Air Layak serta memiliki nilai terendahnya di sektor Penduduk Miskin, Penduduk Miskin Usia 15 Tahun ke Atas Tidak Bekerja, dan Rumah Tangga Miskin yang Menggunakan Jamban Sendiri/Bersama.

4. Kelompok 4 yang terdiri dari Cirebon, Majalengka, Indramayu, dan Karawang memiliki nilai tertinggi di sektor Penduduk Miskin, penduduk miskin usia 15 keatas tamat pendidikan $<$ SD dan Rumah Tangga Miskin yang Menggunakan Jamban Sendiri/Bersama serta memiliki nilai terendahnya di sektor penduduk miskin usia 15 keatas tamat pendidikan SD/SLTP dan Angka Melek Huruf usia $15-55$ th

Kelompok 5 terdiri dari Bandung, Kuningan, Sumedang, Bekasi, dan Bandung Barat memiliki nilai tertinggi di sektor penduduk miskin usia 15 keatas tamat pendidikan SD/SLTP dan Penduduk Miskin Usia 15 Tahun ke Atas Tidak Bekerja.

\section{KESIMPULAN}

Hasil penelitian ini didapat 5 cluster dengan pemetaan karakteristik dari setiap kelompok yang terbentuk berdasarkan nilai rata-rata tertinggi dan terendah dari setiap indikator kemiskinan provinsi Jawa Barat tahun 2018. Dari lima cluster yang terbentuk diperoleh cluster ke-1 yang terdiri dari Bogor, Sukabumi, Cianjur, Garut, Tasikmalaya, Ciamis, Subang, Purwakarta, dan Pangandaran sebagai wilayah yang

ISSN : 2301-7988

E-ISSN : 2581-0588

DOI : $10.32736 /$ sisfokom.v8i2.653 
diprioritaskan dalam peningkatan kesejahteraan penduduknya.

Dengan diketahuinya karakteristik di setiap wilayah, tentunya akan menjadi dasar yang kuat bagi penyelenggara pemerintahan dalam memberikan kebijakan/pendekatan yang tepat dan cepat untuk mengatasi kemiskinan yang terjadi.

Untuk penelitian berikutnya akan lebih baik apabila penelitian ini dapat menambahkan metode untuk menghitung kevalidan dari hasil analisis cluster.

\section{REFERENCES}

[1] L. Ramadhani and I. Purnamasari, "Penerapan Metode Complete Linkage dan Metode Hierarchical Clustering Multiscale Bootstrap ( Studi Kasus : Kemiskinan Di Kalimantan Timur Tahun 2016 ) Application of Complete Linkage Method and Hierarchical Clustering Multiscale Bootstrap Method," vol. 9, no. 2016, pp. 1-10, 2018.

[2] A. Bastian et al., "No Title," no. 1, pp. 26-32.

[3] N. V. Waworuntu and M. F. Amin, "PENERAPAN METODE K-MEANS PEMETAAN CALON," vol. 05, no. 02, pp. 190-200, 2018.

[4] D. Nielza Atthina, "Klasterisasi Data Kesehatan Penduduk untuk Menentukan Rentang Derajat Kesehatan Daerah dengan Metode K-Means," Aseminar Nas. Apl. Teknol. Infromasi, vol. 1, no. Klustering, p. B-52-B-59, 2014.
[5] J. O. Ong, "Implementasi Algotritma K-means clustering untuk menentukan strategi marketing president university," J. Ilm. Tek. Ind., vol. vol.12, no, no. juni, pp. 10-20, 2013.

[6] U. M. Surakarta, "ANALISIS K-MEANS CLUSTER UNTUK PENGELOMPOKAN KABUPATEN / KOTA DI JAWABARAT BERDASARKAN," no. Knpmp Ii, pp. 144-154, 2017.

[7] Ediyanto, M. N. Mara, and N. Satyahadewi, "Pengklasifikasian Karakteristik Dengan Metod KMeans Cluster Analysis," Bul. Ilm., vol. 02, no. 2, pp. 133-136, 2013.

[8] T. Kemiskinan and D. I. Propinsi, "DESCRIPTIVE MODELING MENGGUNAKAN K-MEANS UNTUK PENGCLUSTERAN DESCRIPTIVE MODELLING MENGGUNAKAN K-MEANS UNTUK," no. January, 2017.

[9] R. Hidayat, R. Wasono, and M. Y. Darsyah, "PENGELOMPOKAN KABUPATEN / KOTA DI JAWA TENGAH," pp. 240-250, 2017.

[10] S. Kaputama, "Clustering Pelanggaran Berkendaraan Menggunakan," pp. 1-9.

[11] F. Gullo, "From patterns in data to knowledge discovery: What data mining can do," Phys. Procedia, vol. 62, pp. 18-22, 2015. 